\title{
An Evaluation of Safety Climate in Health Institutions from the Perspective of Intern Students in the Faculty of Health Sciences
}

\author{
Yunus Emre Öztürk
}

Hilal Akman

\section{Ramazan Kıraç ${ }^{c}$}

\begin{abstract}
This is an evaluation of safety climate in health institutions regarding the dimensions of management and healthcare staff from the perspective of intern students in the Faculty of Health Sciences. This study was implemented using the random-sampling method on 204 students who were interns at Selçuk University's Faculty of Health Sciences. Of the 204 given questionnaires, only 200 of these were included in the study. Participants were first asked to provide their demographic information. Afterwards the scale of So, Fang, and Lingard, developed for safetyclimate measurements and then adapted into Turkish, was given to the participants. There were 14 questions on the evaluation of health and safety relating to healthcare staff. These questions used the 5-point Likert scale (strongly disagree $=1$ disagree $=2$, neutral $=3$ agree $=4$, strongly agree $=5$ ). For this study, the reliability of the scale tested at $95 \%$ using the SPSS 20.0 program package. According to reliability analysis for management, Cronbach's Alpha reliability coefficient was .88; for healthcare staff, safety climate's Cronbach Alpha was $.76 \%$. The Cronbach Alpha for the scale's general reliability was calculated at .89\%. A significant difference was found between gender and general safety climate scores $(p<.05)$. As a result of the statistical analysis, women were found to have a more positive safety climate perception in the workplace compared to men. Also, no significant difference was found between the average scores of participants in regard to marital status as compared to general safety climate perception $(p>.05)$. The participants mainly expressed their thoughts on safety climate perception as “unsure."When general safety climate perception was evaluated, a significant difference was observed $(p<.05)$. While nursing interns had negative attitudes regarding safety climate, students from the Departments of Health Management, Social Services, and Midwifery showed unsure attitudes. The vast majority of the participants who were surveyed in the security climate questionnaire were "unsure" about the perception of safety climate.
\end{abstract}

Keywords: Safety culture $\bullet$ Safety climate $\bullet$ Occupational health and safety

a Corresponding author

Asst. Prof. Yunus Emre Öztürk (PhD), Health Management Department, Faculty of Health Sciences, Selçuk University, Konya Turkey

Email: yunuseozturk@gmail.com

b Res. Assist. Hilal Akman, Health Management Department, Faculty of Health Sciences, Selçuk University, Konya Turkey Email: akmanhilal@hotmail.com

c Res. Assist. Ramazan Kıraç, Health Management Department, Faculty of Health Sciences, Selçuk University, Konya Turkey Email: ramazan46k@gmail.com 
With the changing conditions of our globalizing modern world, adverse work conditions as a consequence of enhanced technology and industrialization threaten the health and safety of employees (Tüzüner \& Özaslan, 2011, p. 138).

In today's highly competitive business environment, pressures in the work place to lower costs and minimize lead time, as well as the intensive use of high-tech machinery and equipment at tremendous speed, capacity, and power may further adversely affect the working conditions in these places at some point, which in turn may threaten employees' health and safety (Türen, Gökmen, Tokmak, \& Bekmezci, 2014, p. 171). From a technical and physical point of view, eliminating or diminishing dangers which can be experienced by employees while working constitutes one focal point; at the same time, protection from and treatment of injuries and occupational diseases that may arise as a result of work accidents come to the forefront in terms of health sciences (Demirbilek \& Çakır, 2008, p. 174).

Work accidents and occupational diseases cause significant social and economic losses in both developing and developed countries. Based on statistics issued in Turkey by the Social Security Institution (SGK, 2012), an accident occurs every seven minutes, an employee dies every 10.8 hours, and an employee becomes permanently disabled every 5.5 hours (as cited in Türen et al., 2014, p. 172). In our modern age, work accidents and occupational diseases are among the most significant problems that need to be resolved. Due to the necessity of providing safety to all employees at the highest possible level without regard to age, gender, race or occupation, employee health and occupational safety are vitally important for organizations, administrations, and employees (Türen et al., 2014, p. 172). Occupational health and safety is one of the prominent issues that needs to be resolved in order to ensure employees are working within a safe environment and have sustainable welfare (Akalp \& Yamankaradeniz, 2013, p. 96). Occupational health and safety programs aim to eliminate these problems. According to Tüzüner and Özaslan (2011,p.139), the goal of occupational health and safety is to develop the human behaviors that are needed for a workplace to become a safe working environment, to determine and eliminate direct causes of work accidents and occupational diseases, and to increase efficiency by reducing lost time that may arise as a result of these issues. The World Health Organization (WHO) and International Labor Organization (ILO) define 
employee health as a science aimed at carrying out and sustaining the social, psychological, and occupational welfare of employees at the highest possible level by preventing work conditions that are hazardous to employee health, protecting employees from unhealthy factors related to their employment, and employing people in positions that are suited to their individual physiological and psychological competencies so as to ensure harmony between employees and their work (Akalp \& Yamankaradeniz, 2013, p. 97). Within each step of providing health services, the health system considers some of its priorities to be ensuring a safe environment for both employees and patients, as well as preventing medical errors (Vural, Çiftçi, Fil, Aydın, \& Vural, 2014, p. 152).

When the human factor in a work accident is taken into consideration, it is important to emphasize the effect of the phenomenon of culture on all behaviors, attitudes, and beliefs. The reflection of the phenomena of culture on the issue of occupational health and safety is called safety culture. Safety culture was first mentioned in a report from 1986 prepared for the nuclear accident in Chernobyl. It gained a foothold as an important concept in preventing work accidents (Aytaç, 2011, p. 2). In the Chernobyl report, the facility's weakness concerning safety was mentioned and referred to as one of the reasons for this accident (Özkan \& Lajunen, 2003, p. 3). Safety culture is defined as the integration of health and safety with the style of an organization and the individual, and with the group values, attitudes, perceptions, and behavior patterns that form loyalty (Aytaç, 2011, p. 2). These days see the debate on the differences between the concepts of safety culture and safety climate. Although they are often used in place of one another, it is argued that they possess different characteristics, as reported in Guldenmund (2000) by Özkan and Lajunen (2003, p. 3). Culture is a comprehensive, deep, abstract, learned, and transmitted concept with deep roots. Climate can be described as a reflection of cultural elements on reality in more visible terms.

The concept of safety climate was first used by Zohar in 1980. According to Zohar's definition (1980, p. 101), safety climate is the entirety of information perceived by employees concerning their point-of-view on the safety of an organization. According to Tüzüner and Özaslan (2011, p. 139), the concept of safety climate refers to the level of significance perceived by employees concerning organizational safety performance and the detection of potential system errors before they become a problem. The concept of safety climate 
represents how policies and applications concerning safety are perceived by individual employees. Organizational safety values, as well as the expression of attitudes and behaviors, have an effect while forming this perception in the case of an accident. Perceptions concerning safety climate result from different factors such as administrative decisions, organizational safety norms and expectations, security applications, and policies and procedures, all of which indicate organizational loyalty (Seçer, 2012, p. 38).

\section{Method}

In the present study, data was collected using a scaled survey form. A predetermined sampling group completed the survey form and the collected data was processed via the SPSS statistical software. Choudhry, Fang, and Lingard (2009) developed the applied survey form, and it was adapted into Turkish for measuring safety climate at the workplace. The reliability and validity study for the Turkish form of the scale was conducted by Türen et al. (2014). The reliability and validity of the scale was conducted on employees from the health and electronic sectors. Based on their analyses, it was concluded that the safety climate scale adapted from Choudhry et al.'s study was reliable and valid for Turkey (Türen et al., 2014, p. 184).The questions from the beginning of the survey form were for collecting the participants' demographical data. In the scaled section, 14 questions were for evaluating safety climate from the employees' points of view. These questions were structured in a 5-point Likert model (strongly disagree $=1$, disagree $=2$, not sure $=3$, agree $=4$, strongly agree $=5$ ). The survey has two different dimensions. The first ten questions included in the scale were for evaluating administration in terms of safety climate from the employees' points of view. The following four questions were for evaluating the general safety climate from the employees' points of view. In testing the reliability of this study, the SPSS 20.0 software package showed a reliability of $95 \%$. Based on this analysis, Cronbach's Alpha coefficient regarding the dimension of administration's safety climate was calculated at .88 and Cronbach's Alpha regarding the dimension of employees' safety climate was determined to be .76. Furthermore, the Cronbach alpha coefficient regarding general reliability of the scale was measured at .89. During data analysis, frequency analysis for descriptive statistics, reliability analysis to assess the reliability of the scale, 
t-test for paired comparisons, and ANOVA testing for the comparison of more than two variables were conducted. The population consisted of 200 randomly selected intern students from the Health Sciences Faculty of Selçuk University. Survey forms were distributed to 204 students, but four of them were found to be invalid for inclusion in the study.

\section{Findings}

In this section, the respondents' demographics are presented in Table 1, followed by data corresponding to the first and second dimensions of the scale as shown in the table summary. The first dimension of the scale includes an evaluation of the interns' views on administrator opinions concerning their institutions' safety climate; the second dimension includes an evaluation of employee opinions concerning safety climate.

\begin{tabular}{|c|c|c|c|c|c|}
\hline \multicolumn{6}{|l|}{$\begin{array}{l}\text { Table } 1 \\
\text { Demographic Variables }\end{array}$} \\
\hline Department & $N$ & $\%$ & Marital status & $N$ & $\%$ \\
\hline Health Management & 52 & 26.0 & Married & 6 & 3.0 \\
\hline Social Services & 45 & 22.5 & Single & 194 & 97.0 \\
\hline Midwifery & 49 & 24.5 & Involved in an accident & $\mathbf{N}$ & $\%$ \\
\hline Nursing & 54 & 27.0 & Yes & 20 & 10.0 \\
\hline Gender & $\mathbf{N}$ & $\%$ & No & 180 & 90.0 \\
\hline Male & 47 & 23.5 & Opinion on the necessity of OHS & $\mathbf{N}$ & $\%$ \\
\hline \multirow[t]{2}{*}{ Female } & 153 & 76.5 & Yes & 195 & 97.5 \\
\hline & & & No & 5 & 2.5 \\
\hline
\end{tabular}

Table 1 exhibits the basic demographics of the respondents in both quantity and percentage. According to this information, 26\% of participant intern students were from the Department of Health Management, $22.5 \%$ of them were from the Department of Social Services, $24.5 \%$ were from the Department of Midwifery, and the remaining $27 \%$ of participant intern students were from the Department of Nursing. The majority (76.5\%) of respondents was female and again the vast majority (97\%) of them was single. This number may suggest that the factor affecting this situation could be due to health majors dominantly being women, and that the Departments of Midwifery and Nursing are also usually occupied by women. In addition, the majority of students can be expected to be unmarried as well. According to Table 1, ten percent of the 
employees experienced an accident at work, and the remaining 90\% did not. Finally, while $97.5 \%$ of the respondents felt that occupational health and safety measures were necessary, the remaining $2.5 \%$ did not.

Table 2

Evaluation of administration Opinion Regarding Safety Climate from the Employees' Points of View

\begin{tabular}{lcccccccccccc}
\hline & $\begin{array}{c}\text { Strongly } \\
\text { Disagree }\end{array}$ & Not Agree & Not Sure & Agree & $\begin{array}{c}\text { Strongly } \\
\text { Agree }\end{array}$ \\
\hline & $N$ & $\%$ & $N$ & $\%$ & $N$ & $\%$ & $N$ & $\%$ & $N$ & $\%$ \\
\hline $\begin{array}{l}\text { There are sufficient resources in place for } \\
\text { adequate occupational health and safety at } \\
\text { this work place. }\end{array}$ & 4 & 2.0 & 31 & 15.5 & 82 & 41.0 & 65 & 32.5 & 18 & 9.0 \\
\hline $\begin{array}{l}\text { The company management sincerely } \\
\text { cares about the health and safety issues of } \\
\text { employees. }\end{array}$ & 7 & 3.5 & 37 & 18.5 & 75 & 37.5 & 64 & 32.0 & 17 & 8.5 \\
\hline $\begin{array}{l}\text { In my opinion, the administration takes } \\
\text { necessary measures for safety checks and } \\
\text { accident investigations at this work place. }\end{array}$ & 7 & 3.5 & 37 & 18.5 & 88 & 44.0 & 57 & 28.5 & 11 & 5.5 \\
\hline $\begin{array}{l}\text { The administration shares the results of } \\
\text { safety checks and accident investigations } \\
\text { with employees. }\end{array}$ & 11 & 5.5 & 49 & 24.5 & 81 & 40.5 & 55 & 27.5 & 4 & 2.0 \\
\hline $\begin{array}{l}\text { The administration cares about my opinion } \\
\text { regarding occupational health and safety. }\end{array}$ & 35 & 17.5 & 76 & 38.0 & 55 & 27.5 & 27 & 13.5 & 7 & 3.5 \\
\hline $\begin{array}{l}\text { At this work place, employees always use } \\
\text { the necessary equipment during their } \\
\text { shifts as indicated in the safety and health } \\
\text { regulations. }\end{array}$ & 6 & 3.0 & 46 & 23.0 & 72 & 36.0 & 67 & 33.5 & 9 & 4.5 \\
\hline $\begin{array}{l}\text { At this work place, safety auditing is useful } \\
\text { for developing employees' health and safety } \\
\text { levels. }\end{array}$ & 5 & 2.5 & 27 & 13.5 & 66 & 33.0 & 80 & 40.0 & 22 & 11.0 \\
\hline $\begin{array}{l}\text { The number of personnel is sufficient } \\
\text { during shifts in accordance with health and } \\
\text { safety regulations. }\end{array}$ & 13 & 6.5 & 53 & 26.5 & 61 & 30.5 & 64 & 32.0 & 9 & 4.5 \\
\hline $\begin{array}{l}\text { The companys administration encourages } \\
\text { suggestions in order to develop occupational } \\
\text { health and safety levels. }\end{array}$ & 7 & 3.5 & 50 & 25.0 & 83 & 41.5 & 47 & 23.5 & 13 & 6.5 \\
$\begin{array}{l}\text { The administration cares about occupational } \\
\text { health and safety issues more than efficiency } \\
\text { and profitability. }\end{array}$ & 13 & 6.5 & 50 & 25.0 & 73 & 36.5 & 54 & 27.0 & 10 & 5.0 \\
\hline
\end{tabular}

Table 2 exhibits questions and employee answers regarding administration opinions on safety climate in terms of number and percentage. According to Table 2 , it can be observed that respondents "agree/strongly agree" for the following expressions: "There are sufficient resources in place for adequate occupational health and safety at this work place," (41\%); "The company management sincerely cares about the health and safety issues of employees," (40\%); "At this 
work place, employees always use the required equipment during their shift as indicated in the health and safety regulations," (36\%); "At this work place, safety auditing is useful for developing employees' health and safety levels," (51\%); and "The number of personnel in a shift is sufficient according to the health and safety regulations," (36\%). On the other hand, respondents "strongly disagree/disagree" with these expressions: "The administration cares about my opinion regarding occupational health and safety," (55\%); "The administration shares the results of safety checks and accident investigations with employees" (30\%) and "The administration cares about occupational health and safety issues more than efficiency and profitability" (32\%). In general, it was observed that respondents preferred the option of "not sure."

Table 3

Evaluation of employee Opinions Regarding Safety climate from the Employees' Points of View

\begin{tabular}{lllllllllll} 
& $\begin{array}{c}\text { Strongly } \\
\text { Disagree }\end{array}$ & Disagree & Not Sure & Agree & $\begin{array}{c}\text { Strongly } \\
\text { Agree }\end{array}$ \\
\hline & $N$ & $\%$ & $N$ & $\%$ & $N$ & $\%$ & $N$ & $\%$ & $N$ & $\%$ \\
\hline $\begin{array}{l}\text { I need to pay attention to security measures } \\
\text { during my shift to earn the respect of my } \\
\text { coworkers. }\end{array}$ & 6 & 3.0 & 29 & 14.5 & 36 & 18.0 & 84 & 42.0 & 45 & 22.5 \\
\hline $\begin{array}{l}\text { The majority of safety-at-work trainings } \\
\text { were beneficial. }\end{array}$ & 7 & 3.5 & 33 & 16.5 & 50 & 25.0 & 88 & 44.0 & 22 & 11.0 \\
\hline $\begin{array}{l}\text { All members of my work team are } \\
\text { individually aware of the significance of } \\
\text { occupational health and safety. }\end{array}$ & 6 & 3.0 & 42 & 21.0 & 69 & 34.5 & 65 & 32.5 & 18 & 9.0 \\
\hline $\begin{array}{l}\text { I think my team mates have received } \\
\text { sufficient training in occupational health } \\
\text { and safety. }\end{array}$ & 8 & 4.0 & 43 & 21.5 & 69 & 34.5 & 70 & 35.0 & 10 & 5.0 \\
\hline
\end{tabular}

According to Table 3, expressions regarding the determination of employee points of view on safety climate and their relevant answers to these expressions were shown using numbers and percentages. It can be observed that respondents "agree/strongly agree" with the following expressions: "I need to pay attention to security measures during my shift to earn the respect of my coworkers," (64\%); "The majority of safety-at-work trainings were beneficial," (55\%); "All members of my work team are individually aware of the significance of occupational health and safety," (42\%); and "I think my teammates have received sufficient training in occupational health and safety," (40\%). 


\section{Analysis of the Research}

In the analysis section of this study, a summary table was formed to reveal whether the means of the scores from respondent regarding their opinions on safety climate differed according to gender or marital status. Moreover, another summary table was formed to reveal whether respondents' opinions regarding this research exhibited any difference according to their departmental major. In order to show this information, appropriate statistical methods were utilized.

\begin{tabular}{|c|c|c|c|c|c|}
\hline \multicolumn{6}{|c|}{$\begin{array}{l}\text { Table } 4 \\
\text { The t-Test for Evaluating Respondents' Perceptions Regarding Safety Climate According to Their Demographics }\end{array}$} \\
\hline Intern students' points of view on & Gender & $N$ & Mean & $t$ & $p$ \\
\hline \multirow{2}{*}{ Administration perception of safety climate } & Male & 47 & 2.9087 & \multirow{2}{*}{-1.936} & \multirow{2}{*}{.054} \\
\hline & Female & 153 & 3.1275 & & \\
\hline \multirow{2}{*}{ Employee perception of safety climate } & Male & 46 & 3.0152 & \multirow{2}{*}{-2.322} & \multirow{2}{*}{.021} \\
\hline & Female & 153 & 3.2884 & & \\
\hline \multirow{2}{*}{ General safety climate perception } & Male & 46 & 2.9391 & \multirow[b]{2}{*}{-2.184} & \multirow[b]{2}{*}{.030} \\
\hline & Female & 153 & 3.1734 & & \\
\hline Intern students' points of view on & Marital status & $N$ & Mean & $t$ & $P$ \\
\hline \multirow{2}{*}{ Administration perception of safety climate } & Married & 6 & 2.7667 & \multirow{2}{*}{-.665} & \multirow{2}{*}{.535} \\
\hline & Single & 194 & 3.0835 & & \\
\hline \multirow{2}{*}{ Employee perception of safety climate } & Married & 6 & 3.2750 & \multirow{2}{*}{.185} & \multirow{2}{*}{.853} \\
\hline & Single & 194 & 3.2206 & & \\
\hline \multirow{2}{*}{ General perception of safety climate } & Married & 6 & 2.9119 & \multirow{2}{*}{-.460} & \multirow{2}{*}{.664} \\
\hline & Single & 194 & 3.1227 & & \\
\hline
\end{tabular}

No significant difference was observed with the mean scores of respondents based on gender when compared to their perception of administration point of view regarding safety climate $(p>.05)$. However, a significant difference was found between the mean scores of respondents based on gender when compared to employee perception of safety climate $(p<.05)$; females were more frequently of the opinion that there was a safety climate among employees compared to males. In consideration of the mean scores on the general perception of safety climate, a significant difference was observed in terms of gender $(p<.05)$. As a result of the conducted statistical analysis, it was determined that female respondents had a more positive perception of safety climate at the work place when compared to the males.

No significant difference could be seen between the mean score of respondents based on marital status and the mean score regarding the general perception 
of safety climate $(p>.05)$. In general, respondents remained indecisive in expressing their opinions regarding safety climate.

\begin{tabular}{llllll}
\hline Table 5 & & & & & \\
ANOVA Test for Evaluation of Students' Perceptions of Safety Climate according to their & Departmental Major \\
\hline Intern students' point of view on: & Departmental Major & $N$ & Mean & $f$ & $p$ \\
\hline & Health Management & 52 & 3.0942 & & \\
& Social Services & 45 & 3.0511 & & \\
Administration perceptions of safety climate & Midwifery & 49 & 3.3612 & 6.098 & .001 \\
& Nursing & 54 & 2.8130 & & \\
& Total & 200 & 3.0740 & & \\
\hline & Health Management & 52 & 3.1149 & 3.891 & .010 \\
& Social Services & 45 & 3.1072 & & \\
Employee perception of safety climate & Midwifery & 49 & 3.5138 & & \\
& Nursing & 54 & 3.1569 & & \\
& Total & 200 & 3.2223 & & \\
\hline & Health Management & 52 & 3.1001 & & \\
& Social Services & 45 & 3.0671 & & \\
& Midwifery & 49 & 3.4048 & 5.562 & .001 \\
General perception of safety climate & Nursing & 54 & 2.9112 & & \\
& Total & 200 & 3.1164 & & \\
\hline
\end{tabular}

There was a significant difference between the mean scores of intern students' departmental majors when compared to administration perception of safety climate $(p<.05)$. Students from the nursing department evaluated the administration perception of safety climate more negatively compared to students from other departments. In terms of employee point of view, a significant difference was observed among departmental majors among the students' mean scores of perception of safety climate $(p<.05)$. Students from the Department of Midwifery exhibited a more positive perception of safety climate among employees compared to students from other departments.

In consideration of the general perception of safety climate, a significant difference was again observed among the respondents' departmental majors $(p$ $<.05)$. Whereas students from the Department of Nursing were of the opinion that the general safety climate was negative, students from the Departments of Health Management, Social Services, and Midwifery more often exhibited "unsure" attitudes. 


\section{Conclusion and Results}

In the scope of the study, after reviewing the relevant literature, the scale that was chosen was applied to the sampling group. The Security Climate Scale used in the research was determined to be reliable for this study. Upon analysis of the collected data, descriptive explanations were exhibited in terms of demographics, then any difference in the opinions of intern students from the Health Sciences Faculty of Selçuk University concerning safety climate according to their departmental major was investigated through appropriate statistical methods.

In the study, a significant difference was found regarding the gender of respondents and perception of safety climate in the organization. As a result of statistical analysis, it was determined that females possessed a more positive perception of safety climate compared to the males. On the other hand, no significant relationship was determined to exist between marital status of the respondents and the general perception of safety climate. In general, respondents exhibited indecisive attitudes regarding their opinions on safety climate. In the present research, while taking the differences among respondents' departmental majors into consideration, their perceptions on safety climate regarding their intern work place were analyzed. Based on the performed analysis, the general perception of safety climate was found to exhibit a significant difference according to the respondent's departmental major. Students from the Department of Nursing were of the opinion that there was an adverse general safety climate. On the other hand, students from the Departments of Health Management, Social Services, and Midwifery exhibited indecisive attitudes. Based on the information acquired through the scale, the fact that the vast majority of respondents had an "unsure" stance towards safety climate suggests that respondents were not able to develop an effective opinion regarding their place of employment. At the same time, the indecisive stances exhibited by respondents for exploring their perceptions of safety climate related to administration and their coworkers suggested that they were sufficiently knowledgeable about safety at work. Considering that the respondents were in their senior year and expected to actively commence their professional life soon, a lack of knowledge on occupational health and safety cannot be underestimated. As a result of this study, it was revealed that the knowledge of intern students in the Health Sciences Faculty of Selçuk University regarding the issue of occupational health and safety was insufficient. Furthermore, their 
perceptions on safety climate were not at the expected level. The health sector is a high-risk area in terms of occupational health and safety. In order to ensure the safety of both employees and patients, all employees in this major are required to first be trained in occupational health and safety. Aside from the applicable laws and regulations regarding OHS that are in effect, it is rather important to raise awareness and develop their sensitivity on this issue. In addition to the significance and attention already attached to this issue, the perception of a positive safety climate should be created within the organization by means of in-service training activities, and the expression of attitudes and considerations in the event of a work accident. There is no doubt that occupational health and safety applications are important in all areas. However, since the health sector has no substitute, it is more important for patients as receivers of this service as well as employees. In Aytaç's (2011) study emphasizing the significance of safety culture in preventing work accidents, it was stated that two key elements for establishing safety in the work place were "creating a loyal administration that supports and prioritizes safety at work" and "supporting employee participation and their reliable behavior." Resulting from a study on the impacts of safety climates and work-family conflict on fatigue as reported by Ceyhun (2014), it was determined that employees with strong perceptions of safety have a tendency to develop positive solutions for the problems they face even if they are tired. Akalp and Yamankaradeniz (2013) conducted a study on the administrative role and its significance in forming safety culture in organizations. In their study, they emphasized that establishing a positive and strong safety culture within an organizational structure was an essential factor in the extension of safety-related behaviors and the prevention of work accidents.

In İşler's study (2013) investigating the effect of occupational health and safety training and safety culture on the prevention of work accidents and occupational diseases, it was mentioned that occupational health and safety training for institutionalizing positive attitudes may help create a positive safety culture and is one of the most important tools for raising awareness and consciousness for developing health and safety at work. From this perspective, it is possible to conclude that safe behaviors can be exhibited in climates in which safety culture has been institutionalized. From this angle, importance needs to be attached to safety culture at work, and social groups need to take active participation into account nationally for developing the consciousness of safety 
culture. According to the data obtained in Vural et al.'s study (2014) on health workers' perceptions on patient-safety climate and the reporting of medical errors, it was revealed that employee perception of safety and administration loyalty towards safety were at a medium level. From this finding, the need to develop safety perception was emphasized. There are currently no studies regarding safety climate that have been applied to an extensive sampling group in Turkey. Additionally, in consideration of other studies on safety climate, it has been concluded that safety consciousness is not sufficient in Turkey. In order to prevent or minimize work accidents, safety consciousness first needs to be developed, and safe behaviors at work should be supported. In addition to regulations, creating a positive safety climate and developing awareness for safe behaviors at the administration and employee levels are important factors in the prevention of accidents at work.

\section{References}

Akalp, G.,\&Yamankaradeniz,N.(2013). İ̧ıletmelerde güvenlik kültürünün oluşumunda yönetimin rolü ve önemi. Sosyal Güvenlik Dergisi, 3(2), 96-109.

Aytaç, S. (2011). İ̧̧ kazalarını önlemede güvenlik kültürünün önemi. Türkmetal Dergisi, 17(148), 36-40.

Ceyhun, G. Ç. (2014). Güvenlik iklimi ve iş-aile çatışmasının yorgunluğa etkileri:Türk kılavuz kaptanlar üzerine bir araştırma. Işsletme Araştırmaları Dergisi, 6(2), 91-105.

Choudhry,R.M.,Fang,D., \& Lingard,H.(2009).Measuring safety climate of a construction company. Journal of construction Engineering and Management, 135(9), 890-899.

Demirbilek, T., \& Çakır, Ö. (2008). Kişisel koruyucu donanım kullanımını etkileyen bireysel ve örgütsel değişkenler. Dokuz Eylül Üniversitesi İktisadi ve İdari Bilimler Fakültesi Dergisi, 23(2), 173-191.

İşler, M. ( 2013). İs sağllğg ve güvenliği eğitimleri ile güvenlik kültürünün iş kazası ve meslek hastalıklarının önlenmesindeki etkisi. Ankara: Çalışma ve Sosyal Güvenlik Bakanlığı İş Teftiş Kurulu Başkanlığı.

Özkan, T., \& Lajunen, T. (2003). Güvenlik kültürü ve iklimi. PIVOLKA, 2(10), 3-5.

Seçer, B. (2012). İş sağllğ̆1 ve güvenliğinde psikolojik bir yaklaşım: Atıf kuramı. "İ̧s, Gǚs" Endüstri İliskileri ve İnsan Kaynakları Dergisi, 14(4), 29-46. 
Türen, U., Gökmen, Y., Tokmak, İ., \& Bekmezci, M. (2014). Güvenlik İklimi Ölçeği'nin geçerlilik ve güvenilirlik çalışması. Süleyman Demirel Üniversitesi İktisadi ve İdari Bilimler Fakültesi Dergisi, 9(4), 171-190.

Tüzüner, V. L., \& Özaslan, B. Ö. (2011). Hastanelerde iş sağlı̆̆1 ve güvenliği

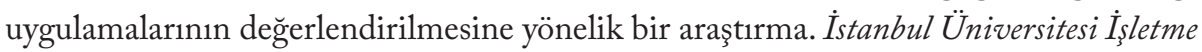
Fakültesi Dergisi, 40(2), 138-154.

Vural, F., Çiftçi, S., Fil, Ş., Aydın, A., \& Vural, B. (2014). Sağlık çalışanlarının hasta güvenliği iklimi algıları ve tıbbı hataların raporlanması. Acıbadem Üniversitesi Sağlık Bilimleri Dergisi, 5(2), 152-157.

Zohar, D. (1980). Safety climate in industrial organizations: Theoretical and applied implications. Journal of Applied Psychology, 65, 96-102. 